\title{
CRISE NA ÁREA DO EURO E SOBERANIA MONETÁRIA: UMA ANÁLISE CRÍTICA
}

\author{
João Guilherme M. A. Monteiro*, Daniela M. Prates.
}

\begin{abstract}
Resumo
A crise na Área do Euro, que foi um desdobramento da crise global de 2008, originada nos Estados Unidos, trouxe à tona as profundas assimetrias existentes entre os países que adotaram esta moeda única. A crise, portanto, se manifestou de maneira distinta entre as nações centrais e as nações periféricas, pejorativamente intituladas como "PIIGS", em referência a Portugal, Irlanda, Itália, Grécia e Espanha. Em meio a esse contexto, traz-se à discussão o conceito de soberania monetária, buscando relacioná-lo à crise e à perda da autonomia de política macroeconômica observada pelos países que fizeram adesão ao euro.
\end{abstract}

\section{Palavras-chave: \\ Área do Euro, Soberania Monetária, Política Macroeconômica.}

\section{Introdução}

A crise financeira de 2008, eclodida nos Estados Unidos em fins daquele ano, teve efeitos em nível mundial. A Área do Euro, composta pelo grupo de nações da União Europeia que fizeram a adesão à moeda única (19 dos 28 membros), foi uma das mais afetadas. Originou-se, assim, uma crise particular e de amplas proporções a estes países. O presente projeto de Iniciação Científica, através da realização de ampla revisão bibliográfica, procura fazer, criticamente, uma análise desta crise, estabelecendo relação com o conceito de soberania monetária.

Neste trabalho, também se faz destaque às assimetrias existentes entre a periferia e o centro da Área do Euro, ressaltando que foram distintas as manifestações da crise para cada nação.

Por fim, procura-se entender como a perda de determinado grau de soberania monetária, resultado do abandono das moedas nacionais em nome da adoção do euro, afetou a respectiva autonomia de política macroeconômica - fato que teve consequências diretas sobre a condução das políticas anticíclicas de combate aos efeitos da crise.

\section{Resultados e Discussão}

Dada a quebra do estado de expectativas e queda no preço dos ativos causados pela eclosão da crise de 2008, houve desaceleração da atividade econômica em termos globais. Na Área do Euro, porém, se desenvolveu uma crise própria, que trouxe consigo as assimetrias estruturais que o projeto da moeda única regional carregava desde sua origem. De um lado, encontram-se as nações centrais, como a Alemanha, que detêm maior poder político e econômico dentro do arranjo institucional da União Europeia; de outro, encontram-se as nações periféricas, como os PIIGS (Portugal, Irlanda, Itália, Grécia e Espanha).

As políticas macroeconômicas anticíclicas - com vistas de fazer frente aos efeitos perversos da crise - adotadas pelos países da Área do Euro se mostraram conservadoras se comparadas às medidas postas em prática pelos Estados Unidos, por exemplo. Isto, em parte, se deve à própria institucionalidade em que estes países estão inseridos, por conta das restrições originadas pela abstenção da emissão de uma moeda nacional, produto da adesão à moeda comum regional. Em outras palavras, a adoção do euro representou uma perda de determinado grau de soberania monetária.
Assim, por decorrência, houve perda da autonomia de política monetária e cambial para estes países, o que implicou, diretamente, em maior restrição à formulação de políticas macroeconômicas com o objetivo de estimular e recuperar a demanda agregada.

Ou seja, alguns instrumentos de política macroeconômica poderiam ter sido mais bem utilizados no contexto da crise, evitando o seu prolongamento e aprofundamento.

Dentre as assimetrias do sistema, há de se ressaltar que os países periféricos foram mais afetados, posto que a crise foi mais aguda em comparação às nações centrais; além disso, havia o diferencial de juros entre a periferia e o centro, por conta do prêmio exigido pelo mercado devido ao maior risco associado às nações periféricas.

Portanto, a perda de autonomia não se deu em igual medida para todos os membros da Área da moeda comum europeia. Enquanto que para os países da periferia as consequências foram mais significativas, para os centrais os efeitos foram mais brandos, ainda que também relevantes.

\section{Conclusões}

A perda de soberania monetária por consequência da adoção do euro revelou uma dura face ao representar a perda de certo grau de autonomia macroeconômica, principalmente em tempos de crise, em que os instrumentos para realização de política anticíclica se encontram restritos.

Além disso, por toda a contextualização apresentada, tem-se que a crise não se manifestaria da mesma forma aos países da Área do Euro, dadas suas assimetrias estruturais que não foram superadas. $E$, consequentemente, a crise se mostrou mais dura às nações periféricas, justamente aquelas que sofreram maior restrição ao uso de políticas macroeconômicas.

\section{Agradecimentos}

Agradeço à contribuição da orientadora, Daniela Magalhães Prates, pelo apoio prestado ao longo de todo o período que compreende desde a submissão até a finalização do projeto. Gostaria também de fazer menção honrosa ao imprescindível trabalho realizado por toda a comunidade acadêmica das universidades públicas do Brasil, com destaque à enorme contribuição que a Universidade Estadual de Campinas presta a toda a sociedade. 